\title{
A single center study of epidemiology of neural tube defects
}

Sir,

Neural tube defects (NTDs) are the most common congenital malformations affecting the brain and spinal cord. They assume significance by virtue of their morbidity, mortality, healthcare expenditure, and human suffering. These defects can be categorized into two groups: Open defects and closed defects. NTDs have a multifactorial etiology. Genetic and environmental factors have been found to cause these defects both individually and in combination. ${ }^{[1]}$

The present study was a hospital-based prospective study which was performed in the Neurosurgical Centre of Sher I Kashmir Institute of Medical Sciences, 
Srinagar and was conducted over a period of 2 years from November 2013 to October 2015.

A detailed history of the mother was taken with special impetus on age, occupation: Housewives/professional worker, dietary history-fruit intake, vegeterian/ nonvegeterian diet, smoking/drug addiction - type/ duration, exposure to fertilizers, folic acid/vitamin intake, any other drugs, number of times conceived/abortions/ intrauterine fetal deaths/previous malformations, mode of delivery, hypertension-treatment/drug defaulter, diabetes - duration and type, tuberculosis, cardiovascular disease, epilepsy - type and duration, etc., Detailed clinical examination of neonate included general physical examination, head circumference, fontanella-lax/full/bulging/tense.

Anencephaly, encephalocele, myelomeningocele, meningocele, lipomeningocele, spina bifida occulted, etc., site of defect: Cranial/cervical/dorsal/lumbar/sacral. Characteristics of defect: Skin covered or not/leaking or not/transilluminant or not, the presence or absence of skin dimple, sinus, hemangioma, hypertrichosis, etc., spine: Normal/scoliosis/kyphosis, other associated malformations, cleft palate, cleft lip, talipes equinovarus hypospadius, etc.

Complete neurological examination of neonate with following, investigations were done X-ray skull: Anterior-posterior (AP) and Lat, $\mathrm{X}$-ray spine: AP and Lat, ultrasonography: Abdomen, magnetic resonance imaging: Spine and brain.

To gauge the most accurate epidemiological pattern of NTDs in Kashmir valley, the patients referred from regions of the state of Jammu and Kashmir other than the valley were excluded from this study.

For statistical analysis, the total number of deliveries in different districts of the Kashmir Valley during the study period was obtained from the Department of Population Research, University of Kashmir which was calculated on the basis of prevailing crude birth rate (taken as average of last 3 years) by Ministry of Health and Family Welfare, Jammu and Kashmir state. Disease frequency was measured by incidence rates.

Incidence rates of NTDs was calculated by the formula: No. of cases that occur

Incidence $=\frac{\text { during a certain period of time }}{\text { No. of births during that time }} \times 1000$

Comparisons were made with other studies conducted by various people from time to time with regards to incidence and possible risk factors. Kashmir valley is topographically and geographically different from rest of the India. It is situated at an altitude of $5000-6000 \mathrm{ft}$, between $33.5^{\circ}$ and $35^{\circ}$ North latitudes and $74-76^{\circ}$ East longitude. It has 10 districts and a total population of $6,907,623$ with a district wise distribution as shown in Table 1 (as per census of India 2011). This study conducted over a period of 2 years from November 2013 to October 2015. The total number of babies with NTDs was 125 with an overall incidence of 0.503 . District Kupwara was having the highest incidence (1.047) and district Srinagar the lowest incidence of NTDs (0.197) as shown in Table 1. The majority of NTDs (116 cases, $92.8 \%$ ) were found in the rural areas (incidence $0.572 / 1000$ births), whereas only 9 cases, i.e., $7.2 \%$ (incidence $0.197 / 1000$ births) were from urban areas. Among the different types of NTDs, spina bifida had an incidence of 0.342 ( 85 cases, 68\%) and anencephaly had an incidence of 0.113 (28 cases, $22.4 \%)$. There was a slight preponderance of females over males with NTDs. There were 70 females (56\%) and 55 males (44\%), respectively, with a male:female ratio of $0.8: 1$. The majority of the patients with anencephaly, i.e., $8(28.6 \%)$ were from district Baramulla, and the majority of patients with encephalocele $4(33.3 \%)$ and spina bifida $22(25.8 \%)$ were from district Kupwara as shown in Tables 2 and 3. The highest number of NTDs was seen in children of primigravida (38.4\%). Spina bifida and encephalocele were also most commonly seen in children of primigravida. History of a previous abortion was present in $17.6 \%$ of the mothers with children having NTDs. About $82.4 \%$ of mothers did not give history of previous abortions. Mothers of only six babies gave history of intrauterine fetal death. Of these two had anencephaly and four had spina bifida in present pregnancy. Mothers of three patients had history

Table 1: District wise population, births per year, distribution and incidence of neural tube defects in Kashmir valley

\begin{tabular}{lcccc}
\hline District & Population & $\begin{array}{c}\text { Number of } \\
\text { births/year }\end{array}$ & $\begin{array}{c}\text { Number of } \\
\text { cases of NTDs } \\
\text { (percentage } \\
\text { of total) }\end{array}$ & $\begin{array}{c}\text { Incidence/ } \\
100 \text { births }\end{array}$ \\
\hline Anantnag & $1,070,144$ & 19,264 & $15(12)$ & 0.389 \\
Badgam & 735,753 & 13,244 & $13(10.4)$ & 0.491 \\
Bandipora & 385,099 & 6932 & $4(3.2)$ & 0.289 \\
Baramulla & $1,015,503$ & 18,279 & $26(20.8)$ & 0.711 \\
Ganderbal & 297,003 & 5346 & $8(6.4)$ & 0.748 \\
Kulgam & 422,786 & 7610 & $6(4.8)$ & 0.394 \\
Kupwara & 875,564 & 15,760 & $33(26.4)$ & 1.047 \\
Pulwama & 570,060 & 10,261 & $9(7.2)$ & 0.439 \\
Shupiyan & 265,960 & 4787 & $2(1.6)$ & 0.209 \\
Srinagar & $1,269,751$ & 22,856 & $9(7.2)$ & 0.197 \\
Total & $6,907,623$ & 124,339 & $125(100)$ & 0.503 \\
\hline
\end{tabular}

NTDs: Neural tube defects 
Table 2: Number and incidence of specific type of neural tube defects

\begin{tabular}{lcccc}
\hline Defect type & \multicolumn{3}{c}{ Percentage of subgroup } & \multirow{2}{\text{Incidence/}}{} \\
\cline { 2 - 4 } & $\begin{array}{c}\text { Number } \\
\text { of boys }\end{array}$ & $\begin{array}{c}\text { Number } \\
\text { of girls }\end{array}$ & $\begin{array}{c}\text { Total } \\
\text { number }\end{array}$ & \\
\hline Anencephaly & $10(35.7)$ & $18(64.3)$ & $28(22.4)$ & 0.113 \\
Encephalocele & $5(41.7)$ & $7(58.3)$ & $12(9.6)$ & 0.048 \\
Spina bifida & $40(47.1)$ & $45(52.9)$ & $85(68)$ & 0.342 \\
Total & $55(44)$ & $70(56)$ & $125(100)$ & 0.503 \\
\hline
\end{tabular}

Table 3: District wise distribution of specific types of neural tube defects

\begin{tabular}{lcccc}
\hline District & \multicolumn{2}{c}{ Percentage of subgroup } & Total \\
\cline { 2 - 4 } & $\begin{array}{c}\text { Anencephaly } \\
\text { number of } \\
\text { cases }\end{array}$ & $\begin{array}{c}\text { Encephalocele } \\
\text { number of } \\
\text { case }\end{array}$ & $\begin{array}{c}\text { Spina } \\
\text { bifida } \\
\text { number } \\
\text { of cases }\end{array}$ & $\begin{array}{c}\text { of cases } \\
\text { (percentage } \\
\text { of total) }\end{array}$ \\
\hline Anantnag & $1(3.6)$ & $0(0)$ & $14(16.5)$ & $15(12)$ \\
Badgam & $3(10.7)$ & $1(8.3)$ & $9(10.6)$ & $13(10.4)$ \\
Bandipora & $1(3.6)$ & $0(0)$ & $3(3.5)$ & $4(3.2)$ \\
Baramulla & $8(28.6)$ & $3(25)$ & $15(17.6)$ & $26(20.8)$ \\
Ganderbal & $2(7.1)$ & $1(8.3)$ & $5(5.9)$ & $8(6.4)$ \\
Kulgam & $2(7.1)$ & $2(16.8)$ & $2(2.4)$ & $6(4.8)$ \\
Kupwara & $7(25)$ & $4(33.3)$ & $22(25.8)$ & $33(26.4)$ \\
Pulwama & $2(7.1)$ & $1(8.3)$ & $6(7.1)$ & $9(7.2)$ \\
Shupiyan & $1(3.6)$ & $0(0)$ & $1(1.2)$ & $2(1.6)$ \\
Srinagar & $1(3.6)$ & $0(0)$ & $8(9.4)$ & $9(7.2)$ \\
\hline
\end{tabular}

of previous malformations. One with encephalocele in present delivery had two previous babies with encephalocele. One with meningomyelocele had previous meningomyelocele and one with meningomyelocele had previous anencephaly. Around $22.4 \%$ of parents gave history of consanguinity of marriage. Such history was not present in $77.6 \%$ of the parents. Exactly $96 \%$ of the mothers with children having NTDs in our study were housewives. Only 4\% were professional workers. Majority of the mothers - 92 cases (73.6\%) in this study consumed folic acid after 28 days of conception. None of the mothers used folic acid before conception. Majority of our patients $93(74.4 \%)$ were from poor and middle class. In our study, majority of the mothers $82(65.6 \%)$ of the NTD affected babies were illiterate. Majority of fathers $84(67.2 \%)$ though literate had an educational level of undergraduate level. Mothers of six neonates in our study were smokers (hookah smoker). None of the mothers was alcoholic. Mother of only one case was having hypertension and was regularly using amlodipine. Mother of one case was having epilepsy and was on sodium valproate which she had used throughout the pregnancy. None of the mothers gave history of diabetes. Mothers of five neonates were of non-Kashmiri origin (4 Bengalis and 1 Maharashtrian) married to Kashmiri male.
The incidence of NTDs varies not only from country to country but also from region to region within a country. The incidence of NTDs in our study was 0.503 per 1000 live births. Nikkilä et al. ${ }^{[2]}$ found the rate of spina bifida among newborns in Sweden to diminish gradually from $0.55 / 1000$ to $0.29 / 1000$ during the study period of 31 years. Agarwal, ${ }^{[3]}$ in their study, found the incidence of NTDs in India to be $0.5-11 / 1000$ live births. Kulkarni and Mathew ${ }^{[4]}$ have found an extremely high incidence of 11.4/1000 live births in Southern India.

The incidence of various types of NTDs in our study was anencephaly (0.113/1000 live births), encephalocele $(0.048 / 1000$ live births) and spina bifida (0.342/1000 live births). Kulkarni et al. ${ }^{[5]}$ in their study in Southern India, found the incidence of anencephaly to be 5.10/1000 live births, encephalocele to be $0.85 / 1000$ live births.

In our study, we found that most of the NTDs 54 (43.2\%) including the subgroups of NTDs, i.e., 14 patients (50\%) of anencephaly, 6 patients (50\%) of encephalocele, and $34(40 \%)$ patients of spina bifida occurred in mothers of younger age group (20-24 years). A number of studies have reported maternal age risk for NTDs to be U-shaped, i.e., highest among youngest and oldest women while other studies have found risk to decrease with increasing age or the reverse. ${ }^{[6]}$ In concordance with our study Vieira and Castillo Taucher ${ }^{[7]}$ in a meta-analysis study of maternal age as risk factor for NTDs, found increased risk associated with mothers of $40+$ years and mothers younger than 19 years. The detected effect was stronger for SB than for anencephaly. Frey and Hauser ${ }^{[8]}$ also reported increased risk of NTDs in older or very young mothers.

Majority of the cases 93 (74.4\%) in our study belonged to low or middle-class families. The socioeconomic status of the families was assessed by modified Prasad's classification. This finding goes in concordance with other studies where increased incidences of NTDs have been found in families of low socioeconomic status. Blanco Muñoz et al. ${ }^{\left[{ }^{[9]}\right.}$ in their study in a Mexican population found increased risk of anencephaly in mothers of low socioeconomic status. Mutchinick et al. ${ }^{[10]}$ found a significantly greater frequency of bricklayers among fathers of anencephalic children than among fathers of healthy children. They attributed this difference to the low socioeconomic level associated with this occupation.

Majority of the mothers $92(73.6 \%)$ in our study had taken folic acid after 28 days of conception. 
Only 12 (9.6\%) of the mothers had consumed folic acid within 28 days of conception and none before conception. In patients who have a family history of an NTD, folic acid taken orally on a daily basis is shown to lower the occurrence and recurrence of NTDs in their own offspring and in their relatives. The Medical Research Council (Group MRCVSR 1991) $)^{[11]}$ was the first to prove conclusively that when women who had had a previous child affected by an NTD took $4.0 \mathrm{mg}$ of folic acid daily, beginning 3 months before conception, there was a $70 \%$ reduction in the recurrence in subsequent offspring.

\section{Financial support and sponsorship \\ Nil.}

\section{Conflicts of interest}

There are no conflicts of interest.

Arif Hussain Sarmast, Masood Ahmed Laharwal, Altaf Umer Ramzan, Abrar Ahad Wani, Nayil Khursheed Malik

Department of Neurosurgery, Sher I Kashmir Institute of Medical Sciences SGR, Srinagar, Jammu and Kashmir, India

Address for correspondence: Dr. Arif Hussain Sarmast,

Dalipora, Kawadara, Srinagar - 190 002, Jammu and Kashmir, India. E-mail: arifhsarmast@gmail.com

\section{References}

1. Cabrera RM, Hill DS, Etheredge AJ, Finnell RH. Investigations into the etiology of neural tube defects. Birth Defects Res C Embryo Today 2004;72:330-44.

2. Nikkilä A, Rydhström H, Källén B. The incidence of spina bifida in Sweden 1973-2003: The effect of prenatal diagnosis. Eur J Public Health 2006;16:660-2.
3. Agarwal SS. Neural tube defect: A preventable congenital malformation. Indian Pediatr 1999;36:643-8.

4. Kulkarni ML, Mathew MA, Ramachandran B. High incidence of neural-tube defects in South India. Lancet 1987;1:1260.

5. Kulkarni ML, Mathew MA, Reddy V. The range of neural tube defects in Southern India. Arch Dis Child 1989;64:201-4.

6. McDonnell RJ, Johnson Z, Delaney V, Dack P. East Ireland 1980-1994: Epidemiology of neural tube defects. J Epidemiol Community Health 1999;53:782-8.

7. Vieira AR, Castillo Taucher S. Maternal age and neural tube defects: Evidence for a greater effect in spina bifida than in anencephaly. Rev Med Chil 2005;133:62-70.

8. Frey L, Hauser WA. Epidemiology of neural tube defects. Epilepsia 2003;44 Suppl 3:4-13.

9. Blanco Muñoz J, Lacasaña M, Borja Aburto VH, Torres Sánchez LE, García García AM, López Carrillo L. Socioeconomic factors and the risk of anencephaly in a Mexican population: A case-control study. Public Health Rep 2005;120:39-45.

10. Mutchinick O, Orozco E, Lisker R, Babinsky V, Núñez C. Risk factors associated with neural tube defects: Exposure during the first trimester of gestation. Gac Med Mex 1990;126:227-33.

11. Prevention of neural tube defects: Results of the medical research council Vitamin study. MRC Vitamin Study Research Group. Lancet 1991;338:131-7.

This is an open access article distributed under the terms of the Creative Commons Attribution-NonCommercial-ShareAlike 3.0 License, which allows others to remix, tweak, and build upon the work non-commercially, as long as the author is credited and the new creations are licensed under the identical terms.

\begin{tabular}{|l|l|}
\hline \multicolumn{2}{|c|}{ Access this article online } \\
\hline Quick Response Code: & Website: \\
\hline & www.ruralneuropractice.com \\
\cline { 2 - 2 } & \\
\hline
\end{tabular}

How to cite this article: Sarmast $A H$, Laharwal MA, Ramzan $A U$, Wani AA, Malik NK. A single center study of epidemiology of neural tube defects. J Neurosci Rural Pract 2016;7:462-5. 